\title{
Özel Yetenekli Öğrencilerin Fen Deneylerine Yönelik Özyeterliklerinin Planlama, Uygulama ve Değerlendirme Bağlamında İncelenmesi
}

\author{
Oğuzhan Nacaroğlua,b, Hatice Esma Güney ${ }^{c}$
}

Özet

$\mathrm{Bu}$ araştırmada, özel yetenekli öğrencilerin fen deneylerine yönelik özyeterliklerinin planlama, uygulama ve değerlendirme açısından incelenmesi amaçlanmıştır. Araştırmada nicel araştırma yöntemi desenlerinden tarama kullanılmıştır. Araştırmanın örneklemini bir Bilim ve Sanat Merkezi'nde öğrenimlerine devam eden 197 özel yetenekli öğrenci oluşturmaktadır. Veri toplama aracı olarak Deneye İlişkin Özyeterlik Ölçeği kullanılmış olup betimsel ve çıkarıma dayalı istatistiksel analizler yürütülmüştür. Araştırma sonucunda katılımcıların fen deneylerine yönelik özyeterliklerinin orta düzeyde olduğu bulunmuştur. Ayrıca katılımcıların ölçeğin değerlendirme boyutunda yer alan maddelere en çok, uygulama boyutunda yer alan maddelere ise en az katılım gösterdikleri tespit edilmiştir. Kız ve erkek katılımcıların ölçekten elde ettikleri toplam puanlar arasında anlamlı bir farklılık bulunmamasına rağmen, proje üretimi ve yönetimi programında öğrenim gören öğrencilerin planlama boyutundan elde ettikleri puan ortalamasının diğer programlarda öğrenim gören öğrencilerin puan ortalamasından yüksek olduğu bulunmuştur.
Anahtar Kelimeler

Özel Yetenekli Öğrenci

Fen Deneyleri

Özyeterlik

Bilim ve Sanat Merkezi

Makale Hakkında

Geliş Tarihi: 09.10.2019

Kabul Tarihi: 26.03.2021

Doi: 10.18026/cbayarsos.631199

\section{Examination of Science Experiments Self-Efficacy of Gifted Students in the Context of Planning, Implementation and Evaluation}

\begin{abstract}
In this research, it was aimed to investigate the self-efficacy of gifted students for science experiments in terms of planning, implementation and evaluation. In the research, survey, one of the quantitative research designs, method was used. The sample of the research consisted of 197 gifted students studying at a Science and Art Center. The Experiment-Related Self-Efficacy Scale was used as the data collection tool and, descriptive and inferential statistical analyzes were conducted. As a result of the research, it was found that the science experiments self-efficacy of the participants was at a medium level. In addition, the participants were found to have the most participation in the items in the evaluation dimension of the scale and the least participation in the items in the implementation dimension. Although there was no significant difference between the total scores obtained from the scale by the girl and boy participants, it was found that the students' score obtained from the planning dimension of the students studying project production and management program was higher than those who were studying other programs.
\end{abstract}

Keywords

Gifted Students

Science Experiments

Self-efficacy

Science and Art Center

About Article

Received: 09.10.2019

Accepted: 26.03.2021

Doi: 10.18026/cbayarsos.631199

a İletişim Yazarı: onacaroglu44@gmail.com

b Dr., Fen Bilimleri Öğretmeni, MEB, https://orcid.org/0000-0001-8516-9152

c Dr., Fen Bilimleri Öğretmeni, MEB, https://orcid.org/0000-0001-5732-3810 


\section{Giriş}

Günümüzde öğrencilerin ilgi ve ihtiyaçlarının değişmesi, bilim, sanayi ve teknolojide yaşanan gelişmeler diğer derslerde olduğu gibi fen bilimleri dersi öğretim programında da farklı zamanlarda güncellemelerin yapılmasını zorunlu kılmıştır. En son yayımlanan fen bilimleri öğretim programı incelendiğinde öğrencilere; güncel problemlere karşı sorumluluk almalarını sağlamak, doğayı keşfederek insan ve çevre etkileşiminin anlaşılması sürecinde bilimsel süreç becerilerini, karar verme ve bilimsel düşünme alışkanlığını kazandırmak gibi özel amaçlarının olduğu görülmektedir (Milli Eğitim Bakanlığı [MEB], 2018). Bununla birlikte fen bilimleri öğretiminin en önemli hedeflerinden birisi, doğayı ve evreni anlayabilen fen okuryazarı birey yetiştirmektir (Arık ve Benli-Özdemir, 2016). Belirtilen becerilerin bireylere kazandırılmasında uygun öğrenme ortamlarının oluşturulması gerekmektedir (Gutierez, 2015; Hassi, 2016). Bu bağlamda fen bilimlerinin öğretimi sürecinde deneysel çalışmaları içeren laboratuvar uygulamalarının yapılması önerilmektedir (Kwok, 2015; Prabha, 2016).

Farklı kültürel alanlarda, farklı yaş gruplarına yönelik sınıflarda ve birçok bilim dalında öğrencilere ders vermek için laboratuvar uygulamaları ve deneysel çalışmalar yürütülmüştür (Hofstain ve Lunetta, 2004). Bununla birlikte doğayı ve evreni anlama sürecinde deneye ve gözleme dayanan bir bilim dalı olan fen bilimlerinde (Karakolcu-Yazıcı ve Özmen, 2015), laboratuvar ve deneysel uygulamalar uzun yıllardır kullanılmaktadır (Chen, Huang ve Chou, 2016). Alan yazın incelendiğinde fen eğitimcileri, öğrencilerin fen laboratuvarı etkinliklerine ve deneysel çalışmalara katılmasının fen bilimleri genel ve özel amaçlarının kazandırılması noktasında önemli olduğunu belirtmişlerdir (Cullin, Hailu, Kupilik ve Petersen, 2017; Hofstein ve Lunetta, 2004; Kwok, 2015; Lazarowitz ve Tamir, 1994; Yavuz ve Akçay, 2017). Nitekim deneysel bir temeli olan fen bilimlerinin öğretiminde öğrencilerin laboratuvar ve deneysel çalışmalara yoğun bir şekilde katılması gerekmektedir (Freeman vd., 2014; Lacey, Campbell, Shaw ve Smith, 2020).

Laboratuvar ve deneysel çalışmalar, öğrencilerin fen bilimleri dersinde öğrendikleri teori ve ilkeleri uygulamalarına imkan veren en etkili öğrenme süreçlerindendir (Meltzer, 2018). Fen bilimleri dersinde yapılan deneyler ve laboratuvar çalışmaları öğrencilerin; bilimsel süreç becerilerine sahip olmasına, bilime karşı olumlu tutum geliştirmelerine ve problem çözme becerileri kazanmasına çok büyük katkı sağlamaktadır (Arzi, 2003; Kılıç, Keleş ve Uzun, 2015; Lopatto, 2007; Tokuhama-Espinosa, 2015). Örneğin Çepni ve Ayvacı (2016), fen bilimleri derslerinde laboratuvar ve deneysel uygulamaların öğrencilerin; bilimsel süreç ve problem çözme becerilerini geliştirdiğini, fen bilimlerine yönelik ilgi ve motivasyonlarını arttırdığını, analiz ve genelleme yeteneklerini geliştirdiğini belirtmişlerdir. Fen bilimleri öğretiminde deneysel uygulamalar öğrencilere geleneksel sinıf formatından farklı öğrenme çevresi sunması nedeniyle de önemli roller üstlenmektedir (Ahmad, Osman, Halim ve Noh, 2014). Ayrıca bu uygulamaların öğrencilerin derse aktif olarak katılmalarını sağladığı ve böylece fen bilimleri dersinde soyut olan kavramların öğrenciler tarafından daha iyi öğrenildiği vurgulanmaktadır (Sarıoğlan, 2015; Yazıcı ve Kurt, 2018). Bu bağlamda Çepni, Kaya ve Küçük (2005), öğrencilerin deneysel çalışmalar esnasında bir dizi problem durumu ile başbaşa bırakılması gerektiğini ve bu problemlerin çözümünde birçok etkinlik yaparak üst düzey kavramsal öğrenme gerçekleştirdiklerini belirtmişlerdir. Aynı şekilde Wardani ve Winarno (2017) da fen derslerinde laboratuvar çalışmalarının öğrenmede etkili olduğunu belirtmişlerdir. Fen derslerindeki deneysel çalışmaların istenilen düzeyde olabilmesi için 
öğrenci özelliklerinin de dikkate alınması önem arz etmektedir (Stuckey, Hofstein, MamlokNaaman ve Eilks, 2013). Nitekim öğrenci başarıları bilgi ve beceri gibi zihinsel süreçlerin yanında tutum, kaygı, özyeterlik ve benlik algısı gibi içsel faktörlerden de etkilenen bir değişkendir (Rockstroh, 2013; Turner ve Lindsay, 2003). Fen bilimleri dersinde öğrencilerin üst düzey kavramsal becerileri kazanabilmesi için laboratuvar deneylerini yapabilecek becerilere ve en önemlisi inanca sahip olmaları gerekmektedir (Yılmaz, 2018). Son yıllarda yapılan çalışmalarda da öğrencilerin akademik başarılarını doğrudan ölçmek yerine özyeterliklerinin de dikkate alınması bu görüşü destekler niteliktedir (Chiang vd., 2020; Shen, Lee, Tsai, ve Chang, 2016).

Özyeterlik, sosyal bilişsel kuramın en önemli öğelerinden birisidir. Bu öğe bireylerin davranışlarının ortaya çıkmasında ve şekillenmesinde etkili olmaktadır. Bandura (1997) özyeterliği, bireylerin belirli bir performansı ortaya koymak için gerekli etkinlikleri organize etme ve başarılı bir şekilde yapma gücüne ilişkin olan kendi yargısı olarak tanımlamıştır. Buradan hareketle bireylerin bir işi başarılı bir şekilde yapabilecekleri yönünde sahip oldukları inançlar, özyeterlik inancı olarak tanımlanabilir (Nabavi, 2012). Özyeterlik, bireylerin eylemlerinin anlaşılması ve değiştirilmesi için önemli bir kavram olmasının yanında belirli eylemlerin nasıl kazanıldığı ve devam ettirildiğini açıklayarak müdahale stratejileri için de temel oluşturmaktadır (Akar, 2011; Usher ve Pajares, 2009).

Bireylerin performanslarını açıklamada önemli bir kavram olan özyeterlik, son yıllarda yapılan bir çok çalışmada incelenen önemli bir değişkendir (Ballen vd., 2017; Hiller ve Kitsantas, 2016; McBride, Oswald, Beck ve Vashlishan Murray, 2020). Nitekim bireylerin sadece bilgi, beceri ve önceki başarıları dikkate alınarak verilen görevi başarılı bir şekilde bitirip bitiremeyeceği tahmin edilememektedir. Ayrıca bireylerin verilen görevleri istenilen düzeyde ve başarılı bir şekilde yerine getirmelerine dair inançları bireylerin eylemlerini etkilemektedir. Bireyler başarılı performanslar sergileyeceklerine inandıkları görevleri yapmaya eğilimli, başarısız performans sergileyeceklerini düşündükleri görevleri ise yapmamaya eğilimli olabilmektedirler (Aydıner, 2011; Kramer ve Winter, 2008; Tarkın ve Uzuntiryaki, 2012). Başka bir ifadeyle özyeterliği yüksek olan bireyler bir işe başlama konusunda daha istekli, zorluklar ile mücadele konusunda daha dirençlidir. Bu bireyler, problemlere daha geniş açıdan bakarak, problemler karşısında daha işlevsel ve kalıcı çözümler üretebilmektedir. Bununla birlikte bireylerin fen bilimlerine ilişkin özyeterlikleri fen başarısı ve mesleki süreklilik açısından önemli görülmektedir (Ferrell ve Barbera, 2015; Randal, 2010). Bu nedenlerden dolayı her kesimdeki bireylerin fen bilimleri özyeterliklerinin yükseltilmesi gerekmektedir. Fen bilimlerinin öğretiminde önemli bir yere sahip olan deneysel çalışmalarda öğrencilerin karşılaşabilecekleri problemlerin tespit edilmesi ve deney yapabilme yeterliliğinin geliştirilmesi için deneye ilişkin özyeterliklerinin bilinmesi gerekmektedir (Damerau, 2013). Bu gruplardan birisi de özel yetenekli öğrencilerin bulunduğu gruptur.

Özel yetenekli birey; aynı çevre şartlarında, aynı yaşta ve deneyimde olan akranlarına göre üstün performans gösteren veya yüksek düzeyde başarı elde eden bireylerdir (Özbay, 2013). MEB (2017) özel yetenekli bireyleri; zekâ, yaratıcılık, sanat, liderlik kapasitesi veya akademik alanlarda yaşıtlarına göre yüksek düzeyde performans gösteren çocuklar olarak tanımlamaktadır. Bu öğrencilerin yakın gelecekte toplumların en önemli karar verme mekanizmalarında yer alma potansiyeli en yüksek öğrenci grubu olduğu ifade edilmektedir (Akbaş ve Çetin, 2018). Dolayısıyla bu öğrencilerin eğitimine ayrı bir önem verilmesi gerekli 
görülmektedir. Türkiye'de bu öğrencilerin eğitiminde Bilim ve Sanat Merkezleri (BİLSEM) önemli görevler üstlenmiştir. BİLSEM sınavlarında başarı gösteren özel yetenekli öğrenciler, okullarındaki öğrenim saatleri dışında BİLSEM'e gelirler ve farklı programlar çerçevesinde eğitim görürler. Her bir programda (Uyum eğitimi, Destek Eğitimi, Bireysel Yetenekleri Fark Ettirme-BYF, Özel Yetenekleri Geliştirme-ÖYG, Proje Üretimi ve Yönetimi) öğrencilerin aktif olarak katılabileceği etkinlikler ve deneysel uygulamalar yapılmaktadır. Yürütülen bu etkinliklerde amaçlanan öğrenme başarısının elde edilebilmesi için öğrencilerin deney yapabilmeye yönelik tahminlerini içeren deneye ilişkin özyeterliklerinin tespitine ve geliştirmesine yönelik çalışmaların yapılması önem arz etmektedir (Damerau, 2012; Yılmaz, 2018). Dolayısıyla mevcut araştırmada, özel yetenekli öğrencilerin fen deneylerine yönelik özyeterlikleri; planlama, uygulama ve değerlendirme açısından incelenmiştir. Bu kapsamda aşağıdaki problemlere cevap aranmıştır:

a. Özel yetenekli öğrencilerin fen deneylerine yönelik özyeterlikleri ne düzeydir?

b. Özel yetenekli öğrencilerin fen deneylerine yönelik özyeterlik puanları cinsiyet değişkeni açısından anlamlı bir farklılık göstermekte midir?

c. Özel yetenekli öğrencilerin fen deneylerine yönelik özyeterlik puanları yaş değişkeni açısından anlamlı bir farklılık göstermekte midir?

d. Özel yetenekli öğrencilerin fen deneylerine yönelik özyeterlik puanları öğrenim görülen program açısından anlamlı bir farklılık göstermekte midir?

\section{Yöntem}

\section{Araştırma Modeli}

Araştırmada özel yetenekli öğrencilerin fen deneylerine yönelik özyeterliklerinin incelenmesi amaçlandığından tarama deseni tercih edilmiştir. Evren hakkında genellenebilir yargıya varmak adına kullanılan tarama deseni, ulaşılabilir evrenin tamamından veya önemli bir kısmından verilerin toplanarak düzenlenmesi ve betimlenmesi süreçlerini içeren bir nicel araştırma desenidir (Karasar, 2006; King ve He, 2005).

\section{Evren ve Örneklem}

Araştırmanın verileri 2019-2020 eğitim-öğretim yılında Doğu Anadolu Bölgesi'nde yer alan bir BİLSEM'deki gönüllü 197 özel yetenekli öğrenciden toplanmıştır. Araştırmanın örneklemi, uygun örnekleme yöntemi kullanılarak ulaşılabilir evrenden seçilmiş ve katılımcılara yönelik demografik bilgiler Tablo 1'de sunulmuştur.

Tablo 1. Katılımcılara Yönelik Demografik Bilgiler

\begin{tabular}{|c|c|c|c|c|}
\hline & Değişkenler & Demografik özellikler & $f$ & $\%$ \\
\hline \multirow{6}{*}{$\begin{array}{l}\text { Özel Yetenekli } \\
\text { Öğrenci }\end{array}$} & \multirow{2}{*}{ Cinsiyet } & K1z & 107 & 54.3 \\
\hline & & Erkek & 90 & 45.7 \\
\hline & \multirow{3}{*}{ Yaş } & $6-10$ & 60 & 30.4 \\
\hline & & 11-15 & 99 & 50.3 \\
\hline & & 16 ve üzeri & 38 & 19.3 \\
\hline & Öğrenim Görülen & Destek eğitimi & 51 & 25.9 \\
\hline
\end{tabular}




$\begin{array}{llll}\text { BİLSEM Programı } & \text { Bireysel Yetenekleri Fark Ettirme (BYF) } & 74 & 37.6 \\ & \text { Özel Yetenekleri Geliştirme (ÖYG) } & 39 & 19.8 \\ & \text { Proje Üretimi ve Yönetimi } & 33 & 16.7\end{array}$

Tablo 1 incelendiğinde, araştırmaya 107 (\%54.3) kız ve 90 (\%45.7) erkek olmak üzere toplam 197 özel yetenekli öğrenci katılmıştır. Bu katılımcıların \%25,9'u destek eğitimi, \%37,6'sı BYF, $\% 19,8$ 'i ÖYG ve \%16,7'si proje üretimi ve yönetimi programlarında öğrenimlerine devam etmektedirler.

\section{Veri Toplama Araci}

$\mathrm{Bu}$ araştırmada veri toplama aracı olarak Damerau (2013) tarafından geliştirilen ve Yılmaz (2018) tarafından Türkçeye uyarlanan Deneye İlişkin Özyeterlik Ölçeği (DÖÖ) kullanılmıştır. Veriler toplanmadan önce ölçeği uyarlayan araştırmacıdan ölçek kullanım izni alınmıştır. Ölçek; planlama, uygulama ve değerlendirme boyutlarından ve 18 maddeden meydana gelmektedir. Planlama boyutunda hipotez kurma, deney planı hazırlama, deney düzeneği tasarlama gibi deney öncesi yapılacak işlemlere yönelik öğrencilerin özyeterliklerini belirlemeye yönelik maddeler yer alırken; uygulama boyutunda deney düzeneğinin kurulması, araç-gereç kullanımı, deney gözlemlerinin yapılması gibi deney sürecinde öğrencilerin özyeterliklerini belirlemeye yönelik maddeler yer almaktadır. Değerlendirme boyutunda ise deney sonuçlarını açıklama ve yorumlama, deney esnasında karşılaşılan hataların tespiti, elde edilen verilerden grafik oluşturma gibi deneysel işlemlerden sonraki süreçlere yönelik öğrencilerin özyeterliklerinin belirlemesine yönelik maddeler bulunmaktadır. Ölçeğin boyutları ve örnek maddeleri Tablo 2' de sunulmuştur.

Tablo 2. Ölçeğe ait Boyutlar ve Örnek Maddeler

\begin{tabular}{llll}
\hline Ölçek & $\begin{array}{l}\text { Ölçek } \\
\text { Boyutları }\end{array}$ & Maddeler & Örnek madde \\
\hline \multirow{2}{*}{ DöÖ } & Planlama & $1-2-3-4-5-6$ & $\begin{array}{l}\text { Bir deney için hangi araçların/malzemelerin gerekli } \\
\text { olduğunu saptamakta iyiyimdir. }\end{array}$ \\
\cline { 2 - 3 } & Uygulama & $7-8-9-10-11-12$ & $\begin{array}{l}\text { Deneyde gerekli olan araç-gereçlerin kullanımında } \\
\text { zorlanmam. }\end{array}$ \\
\cline { 2 - 4 } & Değerlendirme & $13-14-15-16-17-18$ & $\begin{array}{l}\text { Deney verilerinden grafik oluşturulmasında } \\
\text { zorlanmam. }\end{array}$ \\
\hline
\end{tabular}

Ölçek iki eğitim uzmanı ve bir Türkçe öğretmenine sunulmuştur. Bu kapsamda eğitim uzmanları ölçeği özel yetenekli öğrencilere uygunluğu; Türkçe öğretmeni ise anlaşılırlık, imla ve yazım kuralları bağlamında incelemişlerdir. Değerlendirmeler sonucunda, BİLSEM'lerde yoğun bir şekilde yürütülen deneysel işlemler göz önüne alındığında ölçeğin bu öğrencilerin deneylere yönelik özyeterliklerini inceleme noktasında kullanılabileceğine dair eğitim uzmanları ortak görüş bildirmişlerdir. Veri toplama aracının güvenirliğini sağlamak için Cronbach Alfa güvernirlik katsayısı hesaplanmıştır. Yılmaz (2018) tarafından ölçeğin güvenirlik katsayısı 0.92; mevcut araştırmada ise 0.78 olarak hesaplanmıştır. 


\section{Verilerin Toplanması ve Analizi}

Verilerin toplanması sürecinde öncelikle araştırmaya katılmak isteyen öğrencilerin gönüllü katılım formunu doldurmaları sağlanmıştır. Daha sonra DÖÖ katılımcıların uygun oldukları zaman dikkate alınarak uygulanmıştır. Uygulama öncesi katılımcllara ölçek hakkında bilgiler verilmiş, istedikleri zaman çalışmadan çekilebilecekleri belirtilmiş ve ardından uygulamaya geçilmiştir. Toplanan verilerin analizinde betimsel ve çıkarıma dayalı istatistiksel analizler yapılmıştır. Ölçekten elde edilen puanların cinsiyet, BİLSEM programı ve yaş değişkenine göre normal dağılıp dağılmadığı kontrol edilmiş ve belirlenen değerler Tablo 3'te sunulmuştur.

Tablo 3. Ölçek Puanlarına ait Betimsel İstatistik Sonuçları

\begin{tabular}{|c|c|c|c|c|c|c|c|}
\hline Ölçek & Değişkenler & Ort. & Medyan & Çarpıklık & Basıklık & Min. & Mak. \\
\hline \multirow{9}{*}{$\begin{array}{l}\text { :ం } \\
: \bigcirc \\
\text { م }\end{array}$} & $\vec{D}$ Erkek & 66.64 & 66.50 & .388 & .133 & 47 & 90 \\
\hline & ङ $\mathrm{K}_{1 \mathrm{Z}}$ & 67.58 & 67.00 & .399 & .281 & 46 & 90 \\
\hline & Destek eğitimi & 65.68 & 65.00 & .712 & .836 & 47 & 87 \\
\hline & $\sum_{[=1} \Xi_{\tilde{\sigma}} \mathrm{BYF}$ & 66.70 & 67.50 & .006 & .224 & 46 & 90 \\
\hline & 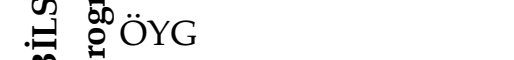 & 66.74 & 67.00 & .077 & -.008 & 47 & 84 \\
\hline & Proje üretimi ve yönetimi & 70.93 & 71.00 & .153 & -.849 & 49 & 90 \\
\hline & $6-10$ & 66.16 & 65.50 & .547 & .735 & 47 & 87 \\
\hline & $11-15$ & 66.51 & 66.00 & .049 & -.027 & 46 & 90 \\
\hline & 16 ve üzeri & 70.39 & 69.00 & 283 & -.576 & 49 & 90 \\
\hline
\end{tabular}

Katılımcıların DÖÖ’den aldıkları puanların değişkenler açısından normal dağılım gösterdiği söylenebilir (Fraenkel ve Wallen, 2006). Nitekim verilerin basıklık ve çarpıklık değerleri -1 ile +1 arasında değişmektedir. Bunun yanında ortalama ile medyan değerleri ise birbirine oldukça yakın değerlerdir. Bu açıklamalar neticesinde; ölçekten alınan puanların cinsiyet değişkeni açısından karşılaştırılmasında bağımsız örneklem $t$ testi; yaş ve BİLSEM programı açısından karşılaştırılmasında ise ANOVA yapılmıştır.

\section{Bulgular}

\section{Özel Yetenekli Öğrencilerin Fen Deneylerine Yönelik Özyeterlikleri}

Araştırmada ilk olarak "Özel yetenekli öğrencilerin fen deneylerine yönelik özyeterlikleri ne düzeydir?" birinci alt problemine cevap aranmıştır. Bu kapsamda ölçeğin genelinden ve alt boyutlarından alınan puanlara ilişkin betimsel istatistik sonuçları Tablo 4 'te sunulmuştur.

Tablo 4. DÖÖ’den Alınan Puanlara Ait Betimsel İstatistik Bulguları

\begin{tabular}{lccccc}
\hline Döö & $\mathbf{N}$ & $\overline{\mathrm{X}}$ & $\mathbf{s}$ & Min. & Max. \\
\hline Planlama & 197 & 3.70 & 3.95 & 11 & 30 \\
Uygulama & 197 & 3.69 & 3.58 & 10 & 30 \\
Değerlendirme & 197 & 3.78 & 3.63 & 14 & 30
\end{tabular}


Tablo 4 incelendiğinde, katılımclar DÖÖ’den en düşük (46), en yüksek (90) puan almışlardır. Ölçeğin genelinden alınan toplam puan ortalaması $(\bar{X}=3.73)$ olarak bulunmuştur. Katılımcılar ölçeğin geneli $(\bar{X}=3.73)$ ile Planlama $(\bar{X}=3.70)$, Uygulama $(\bar{X}=3.69)$ ve Değerlendirme ( $\overline{\mathrm{X}}=3.78$ ) alt boyutlarına "Katılıyorum" şeklinde görüşlerini ifade etmişlerdir. Planlama boyutunda yer alan maddelere ait ortalama ve standart sapma değerleri Tablo 5 'te verilmiştir.

Tablo 5. Planlama Maddelerine Ait Aritmetik Ortalama ve Standart Sapma Değerleri

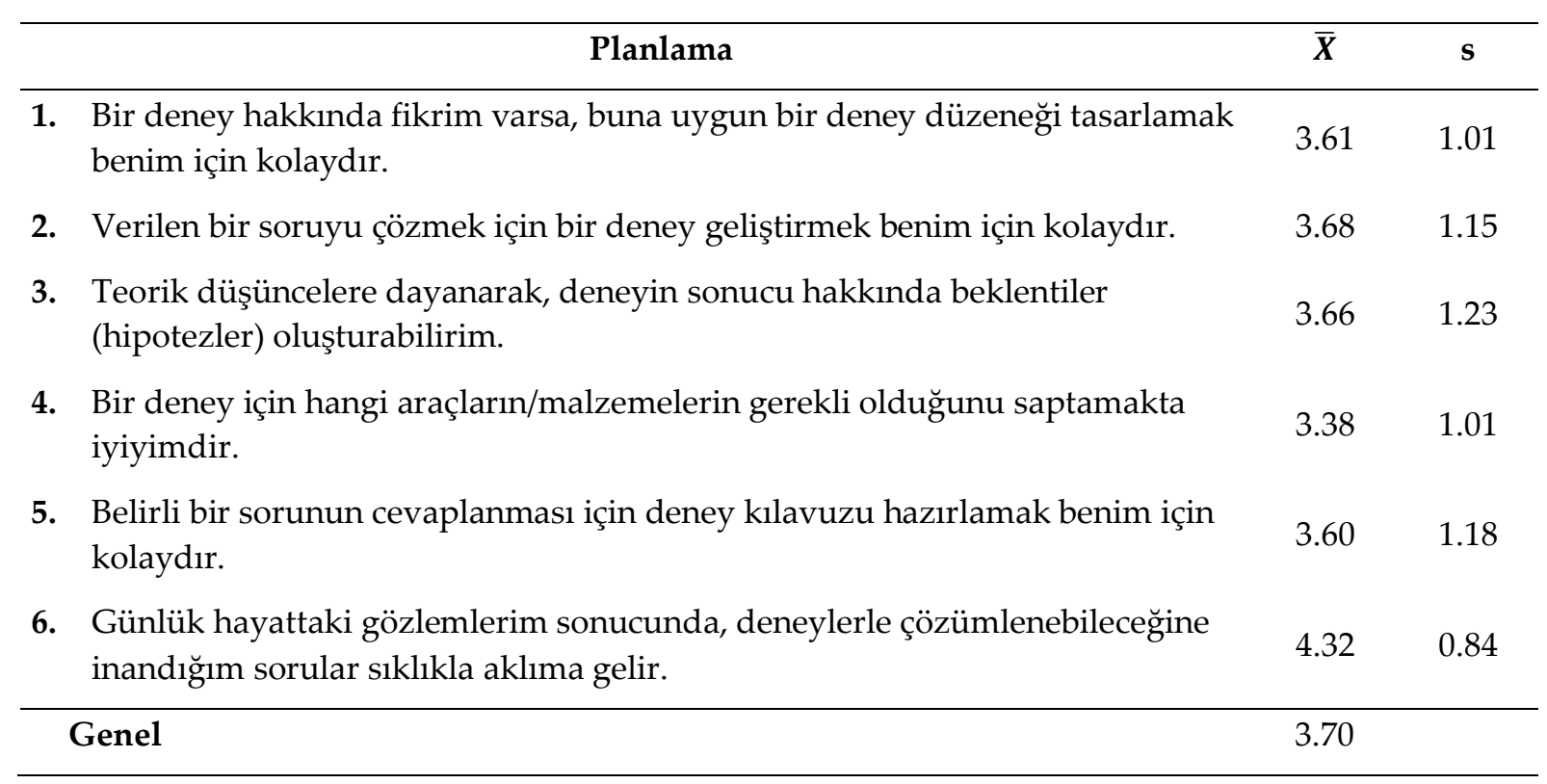

Tablo 5 incelendiğinde, katılımcların Planlama boyutunda yer alan "Günlük hayattaki gözlemlerim sonucunda, deneylerle çözümlenebileceğine inandığım sorular sıklıkla aklıma gelir." maddesine en çok $(\overline{\mathrm{X}}=4.32)$, "Bir deney için hangi araçları/malzemelerin gerekli olduğunu saptamakta iyiyimdir." maddesine ise en az ( $\overline{\mathrm{X}}=3.38)$ katılım gösterdikleri görülmektedir. Uygulama boyutunda yer alan maddelere ait ortalama ve standart sapma değerleri Tablo 6'da verilmiştir.

Tablo 6. Uygulama Maddelerine Ait Aritmetik Ortalama ve Standart Sapma Değerleri

\begin{tabular}{llcc}
\hline \multicolumn{1}{c}{ Uygulama } & $\overline{\boldsymbol{X}}$ & $\mathbf{s}$ \\
\hline 7. Laboratuvar araç-gereçleri kullanımında iyiyimdir. & 4.20 & 1.02 \\
8. Deneylerin uygulama aşamasında el yeteneğim yoktur. & 3.73 & 1.13 \\
9. Deney gözlemlerini yazarken zorlanırım. & 3.44 & 1.23 \\
10. Deney düzeneği kurarken zorlanmam. & 3.39 & 1.20 \\
11. Deneylerin yürütülmesinde başarılıyımdır. & 3.63 & 1.12 \\
12. Deneyde gerekli olan araç-gereçlerin kullanımında zorlanmam. & 3.78 & 1.07 \\
\hline Genel & 3.69 & \\
\hline
\end{tabular}


Tablo 6 incelendiğinde, katılımcıların Uygulama boyutunda yer alan "Laboratuvar araçgereçleri kullanımında iyiyimdir." maddesine en çok $(\overline{\mathrm{X}}=4.20)$, "Deney düzeneği kurarken zorlanmam." maddesine ise en az ( $\overline{\mathrm{X}}=3.39)$ katılım gösterdikleri görülmektedir. Katılımcıların Değerlendirme boyutunda yer alan maddelere ait ortalama ve standart sapma değerleri Tablo 7'de verilmiştir.

Tablo 7. Değerlendirme Maddelerine Ait Aritmetik Ortalama ve Standart Sapma Değerleri

\begin{tabular}{|c|c|c|}
\hline Değerlendirme & $\overline{\mathbf{X}}$ & $\mathbf{s}$ \\
\hline 13. Ölçüm verilerini değerlendirmekte zorlanmam. & 4.11 & 0.89 \\
\hline 14. Deney gözlemlerini açıklamakta sorun yaşamam. & 3.84 & 1.11 \\
\hline 15. Deney sonuçlarını yorumlamakta genelde zorluk yaşarım. & 4.07 & 1.00 \\
\hline 16. Bir deneyden elde edilen sonuçları değerlendirirken zorlanmam. & 3.42 & 1.29 \\
\hline $\begin{array}{l}\text { 17. Planladığım gibi yürümeyen bir deneydeki muhtemel hata kaynaklarını } \\
\text { bulmakta zorlanmam. }\end{array}$ & 3.59 & 1.09 \\
\hline 18. Deney verilerinden grafik oluşturulmasında zorlanmam. & 3.70 & 1.00 \\
\hline Genel & 3.78 & \\
\hline
\end{tabular}

Tablo 7 incelendiğinde, katılımcıların Değerlendirme boyutunda yer alan "Ölçüm verilerini değerlendirmekte zorlanmam." maddesine en çok $(\overline{\mathrm{X}}=4.11)$, "Bir deneyden elde edilen sonuçları değerlendirirken zorlanmam." maddesine ise en az ( $\overline{\mathrm{X}}=3.42)$ katılım gösterdikleri görülmektedir.

\section{Cinsiyet Açısından Fen Deneylerine Yönelik Özyeterlik Puanlarının Karşılaştırılması}

Araştırmada "Özel yetenekli öğrencilerin fen deneylerine yönelik özyeterlik puanlar cinsiyet değişkeni açısından anlaml bir farklılık göstermekte midir?" ikinci alt problemine cevap aranmıştır. Bu kapsamda kız ve erkek katılımcıların ölçekten aldıkları puanlara ait analiz sonuçları Tablo $8^{\prime}$ de verilmiştir.

Tablo 8. Cinsiyet Açısından Bağımsız Örneklem t Testi Sonuçları

\begin{tabular}{llcccccc}
\hline Boyut & Cinsiyet & $\mathbf{N}$ & $\overline{\boldsymbol{X}}$ & $\mathbf{s}$ & $\mathbf{s d}$ & $\mathbf{t}$ & $\mathbf{p}$ \\
\hline Planlama & Erkek & 90 & 22.70 & 4.15 & 195 & 1.474 & .142 \\
& Kız & 107 & 21.86 & 3.74 & & & \\
\hline \multirow{2}{*}{ Uygulama } & Erkek & 90 & 21.97 & 3.57 & \multirow{2}{*}{195} & -0.717 & .474 \\
& Kız & 107 & 22.34 & 3.59 & & & \\
\hline \multirow{2}{*}{ Değerlendirme } & Erkek & 90 & 21.96 & 3.93 & \multirow{2}{*}{195} & -2.754 & .006 \\
& Kız & 107 & 23.37 & 3.23 & & & \\
\hline \multirow{2}{*}{ Ölçeğin Geneli } & Erkek & 90 & 66.64 & 9.52 & \multirow{2}{*}{195} & -0.727 & .468 \\
& Kız & 107 & 67.58 & 8.68 & & & \\
\hline
\end{tabular}

Tablo 8 incelendiğinde, kız ve erkek katılımcıların ölçeğin genelinden aldıkları ortalama puanlar arasında (Kız katılımcl=67.58, Erkek katılımcl=66.64) istatistiksel olarak anlamlı 
düzeyde bir farklılık bulunmamıştır [t(195) $=-0.727 ; p=.46>.05]$. Buna karşın Değerlendirme alt boyutundan alınan puanlar arasında kız katılımclar lehine anlamlı bir farklılık tespit edilmiştir [t(195) $=-2.754 ; \mathrm{p}=.006<.05]$.

\section{Yaş Açısından Fen Deneylerine Yönelik Özyeterlik Puanlarının Karşılaştırılması}

Araştırma “Özel yetenekli öğrencilerin fen deneylerine yönelik özyeterlik puanları yaş değişkeni açısından anlamlı bir farklılık göstermekte midir?" üçüncü alt problemine cevap aranmıştır. Bu kapsamda grup istatistikleri ile ANOVA sonuçları sırasıyla Tablo 9 ve Tablo 10'da verilmiştir.

Tablo 9. Yaş Değişkenine Ait Grup İstatistikleri

\begin{tabular}{lcccc}
\hline Yaş & $\mathbf{N}$ & $\overline{\boldsymbol{X}}$ & $\mathbf{s}$ & Standart hata \\
\hline 6-10 yaş & 60 & 66.16 & 8.15 & 1.15 \\
11-15 yaş & 99 & 66.51 & 8.50 & 0.85 \\
16 ve üzeri & 38 & 70.39 & 11.17 & 1.81 \\
Toplam & 197 & 67.15 & 9.07 & 0.64 \\
\hline
\end{tabular}

Tablo 10. ANOVA Sonuçları

\begin{tabular}{|c|c|c|c|c|c|c|c|}
\hline Ölçek & Boyutlar & Varyans Kaynağı & Kareler toplamı & $\mathrm{df}$ & Kareler ort. & F & $\mathrm{p}$ \\
\hline \multirow{12}{*}{ : } & \multirow{3}{*}{ Planlama } & Gruplar arası & 103.303 & 2 & 51.652 & \multirow{3}{*}{3.388} & \multirow{3}{*}{.036} \\
\hline & & Gruplar içi & 2957.509 & 194 & 15.245 & & \\
\hline & & Toplam & 3060.812 & 196 & & & \\
\hline & \multirow{3}{*}{ Uygulama } & Gruplar arası & 53.985 & 2 & 29.993 & \multirow{3}{*}{2.128} & \multirow{3}{*}{.122} \\
\hline & & Gruplar içi & 2460.797 & 194 & 12.685 & & \\
\hline & & Toplam & 2514.782 & 196 & & & \\
\hline & \multirow{3}{*}{ Değerlendirme } & Gruplar arası & 29.334 & 2 & 14.667 & \multirow{3}{*}{1.113} & \multirow{3}{*}{.331} \\
\hline & & Gruplar içi & 2555.407 & 194 & 13.172 & & \\
\hline & & Toplam & 2584.741 & 196 & & & \\
\hline & \multirow{3}{*}{ Ölçeğin Geneli } & Gruplar arası & 497.982 & 2 & 248.991 & \multirow{3}{*}{3.091} & \multirow{3}{*}{.048} \\
\hline & & Gruplar içi & 15626.140 & 194 & 80.547 & & \\
\hline & & Toplam & 16124.122 & 196 & & & \\
\hline
\end{tabular}

Tablo 10 incelendiğinde, yaş değişkeni açısından katılımcların ölçeğin genelinden [F(2-194) =3.091; $\mathrm{p}=.048<.05]$ ve planlama boyutundan aldiklar1 puanlar $[\mathrm{F}(2-194)=3.388 ; \mathrm{p}=.036<.05]$ arasında anlamlı bir farklılık bulunmuştur. Post Hoc testi (LSD) bulguları, 16 ve üzeri yaşa sahip öğrencilerin ölçeğin ölçeğin genelinden ve planlama alt boyutundan aldıkları puan ortalamasının diğer yaş grubundaki öğrencilerin puan ortalamalarından daha yüksek olduğunu göstermiştir. Buna karşın yaş değişkeni açısından uygulama ve değerlendirme alt boyutlarından alınan puanlar arasında anlamlı bir farklılık yoktur (p>.05). 
Özel Yetenekli Öğrencilerin Fen Deneylerine Yönelik Özyeterliklerinin Planlama, Uygulama ve Değerlendirme Bağlamında İncelenmesi

\section{BİLSEM Programı Açısından Fen Deneylerine Yönelik Özyeterlik Puanlarının Karşılaştırılması}

Araştırma kapsamında “Özel yetenekli öğrencilerin fen deneylerine yönelik özyeterlik puanları öğrenim görülen program açısından anlamlı bir farklılık göstermekte midir?" dördüncü alt problemine cevap aranmıştır. Bu kapsamda grup istatistikleri ve ANOVA sonuçları sırasıyla Tablo 11 ve Tablo 12' de verilmiştir.

Tablo 11. BİLSEM Programina Ait Grup İstatistikleri

\begin{tabular}{lcccc}
\hline Program & $\mathbf{N}$ & $\overline{\boldsymbol{X}}$ & $\mathbf{s}$ & Standart hata \\
\hline Destek Eğitimi & 51 & 65.68 & 8.51 & 1.19 \\
BYF & 74 & 66.70 & 8.37 & 0.97 \\
ÖYG & 39 & 66.74 & 7.76 & 1.24 \\
Proje Üretimi ve Yönetimi & 33 & 70.93 & 11.83 & 2.06 \\
\hline
\end{tabular}

Tablo 12. ANOVA Sonuçları

\begin{tabular}{|c|c|c|c|c|c|c|c|}
\hline \multicolumn{2}{|c|}{ Ölçek Boyutlar } & \multirow{2}{*}{$\begin{array}{l}\text { Varyans Kaynağ1 } \\
\text { Gruplar arası }\end{array}$} & \multirow{2}{*}{$\begin{array}{c}\text { Kareler toplamı } \\
125.701\end{array}$} & \multirow{2}{*}{$\frac{d f}{3}$} & \multirow{2}{*}{$\begin{array}{c}\text { Kareler ort. } \\
41.900\end{array}$} & \multirow[t]{2}{*}{$\mathbf{F}$} & \multirow[t]{2}{*}{$\mathbf{P}$} \\
\hline \multirow{12}{*}{ : } & & & & & & & \\
\hline & \multirow[t]{3}{*}{ Planlama } & Gruplar içi & 2935.111 & 193 & 15.208 & 2.755 & .044 \\
\hline & & Toplam & 3060.812 & 196 & & & \\
\hline & & Gruplar arası & 77.524 & 3 & 25.841 & & \\
\hline & \multirow[t]{3}{*}{ Uygulama } & Gruplar içi & 2437.257 & 193 & 12.628 & 2.046 & .109 \\
\hline & & Toplam & 2514.782 & 196 & & & \\
\hline & & Gruplar arası & 67.291 & 3 & 22.430 & & \\
\hline & \multirow[t]{3}{*}{ Değerlendirme } & Gruplar içi & 2517.450 & 193 & 13.044 & 1.720 & .164 \\
\hline & & Toplam & 2584.741 & 196 & & & \\
\hline & & Gruplar arası & 604.367 & 3 & 241.456 & & \\
\hline & \multirow[t]{2}{*}{ Toplam } & Gruplar içi & 15519.755 & 193 & 80.413 & 2.505 & .060 \\
\hline & & Toplam & 16124.122 & 196 & & & \\
\hline
\end{tabular}

Tablo 12 incelendiğinde, BİLSEM programı açısından katılımcıların ölçeğin genelinden aldıkları puanlar arasında anlamlı bir farklılık tespit edilmemiştir. $[\mathrm{F}(2-193)=2.505$; $\mathrm{p}=.060>.05]$. Buna karşın planlama boyutundan alınan puanlar arasında anlamlı bir farklılık vardır $[\mathrm{F}(2-193)=2.755 ; \mathrm{p}=.044<.05]$. Post Hoc testi (LSD) bulguları, proje üretimi ve yönetimi programındaki katılımcıların planlama alt boyutundan aldıkları puan ortalamasının diğer programlardaki öğrencilerin puan ortalamalarından daha yüksek olduğunu göstermiştir. 


\section{Tartışma, Sonuç ve Öneriler}

$\mathrm{Bu}$ araştırmada, özel yetenekli öğrencilerin fen deneylerine yönelik özyeterliklerinin planlama, uygulama ve değerlendirme bağlamında incelenmesi amaçlanmıştır. Bu kapsamda gönüllü 197 özel yetenekli öğrenci ile araştırma yürütülmüştür. Birinci alt problem kapsamında katılımcıların fen deneylerine yönelik özyeterlik puanlarının değerlendirme boyutunda en yüksek, uygulama boyutunda ise en düşük olduğu sonucuna ulaşılmıştır (Tablo 4). Bu sonuç, üzerinde durulması gereken önemli konulardandır. Her ne kadar laboratuvar ve deneysel uygulamalar fen bilimleri dersi için önem arz etse de (Lacey vd., 2020; Pareek, 2019), deneysel çalışmalarda öğrencilere istenilen becerileri kazandırabilmek için öğretmen yeterliğinin (Clotfelter, Ladd ve Vigdor, 2007; Shapiro vd., 2015) yanı sıra öğrenci özelliklerinin ve öğrenme ortamlarının da dikkate alınması gerekmektedir (Stuckey vd., 2013). Nitekim uygulama sonrası katılımcıların fen deneylerine yönelik özyeterliklerinin yüksek, buna rağmen uygulama aşamasında özyeterliklerinin düşük olmasından dolayı fen bilimleri derslerinde deneysel uygulamaların yeterince yapılmadığı yorumu yapılabilir. BİLSEM'lerde fen bilimleri derslerinin büyük bir çoğunluğu deneysel uygulamalar şeklinde olmasına karşın bu sonucun ortaya çıkmasında öğrencilerin devam ettikleri okullarına kıyasla BİLSEM'deki eğitimlere çok az zaman ayırmalarının etkili olduğu düşünülmektedir. Bununla birlikte öğrencilerin planlama boyutunda yer alan "Günlük hayattaki gözlemlerim sonucunda, deneylerle çözümlenebileceğine inandığım sorular sıklıkla aklıma gelir." maddesine en çok (Tablo 5), uygulama boyutunda yer alan "Deney düzeneği kurarken zorlanmam." maddesine en az (Tablo 6) katılım göstermeleri de bu öğrencilerin eğitimlerinde yeterince deneysel uygulamalar yapılmadığına yönelik ipucu vermektedir. Dolayısıyla geleceğin bilim insanı olmaya en yakın aday olarak gösterilen, karşılaştıkları problemleri sorgulayarak çözmeyi seven ve zor olan görevleri tercih etmede istekli olan (Coleman, Micko ve Cross, 2015; Schreglmann, 2016) bu öğrencilerin eğitimlerinde deneysel uygulamalar içeren öğrenme faaliyetlerinin arttırılması önemli görülmektedir.

Özel yetenekli öğrencilerin deneysel uygulamalara yönelik özyeterliklerinin düşük olmasına başka durumların da sebep olabileceği göz ardı edilmemelidir. Alanyazında, öğretmenlerin laboratuvar uygulamalarına yönelik yetersizliği, deney malzemelerinin eksikliği, deney yapmak için yeterli sürenin olmaması, deneysel çalışmalar esnasında yaşanan kazalar, uygun planlamanın yapılmaması gibi sebeplerden dolayı deneysel çalışmalarının yeterince yapılmadığı ifade edilmektedir (Alpaut, 1993; Backus, 2005; Hackling, Goodrum ve Rennie, 2001; Hofstein ve Lunetta, 2004). Buradan hareketle, özel yetenekli öğrencilerin fen deneyleri uygulama aşamasında özyeterliklerini yükseltmek için yukarıda belirtilen olumsuz durumların en aza indirilmesi ve bu öğrencilerin sahip oldukları potansiyellerinin farkına varabilmeleri için fen bilimleri dersinde mümkün olduğunca deneysel uygulamalara yer verilmesi önem arz etmektedir.

Kız ve erkek katılımcıların fen deneylerine yönelik özyeterlik ölçeğinden aldıkları toplam puanlar arasında anlamlı bir farklılığın olmadığı; değerlendirme boyutunda ise kız katılımcılar lehine anlamlı bir farklılığın olduğu sonucuna ulaşılmıştır (Tablo 8). Deneysel çalışmaların değerlendirme boyutunda, verilerin ve sonuçların yorumlanması, ortaya çıkan problemlerin ele alınması ve gözden geçirilmesi gerekmektedir (Yılmaz, 2018). Buradan hareketle kız katılımcıların deneysel uygulamaları değerlendirme sürecinde; veri yorumlama, sonuçları analiz etme, ortaya çıkan olası hataları belirleme ve verilere yönelik 
grafik oluşturma noktasında erkek katılımcılara göre daha yüksek özyeterlik becerilerine sahip oldukları yorumu yapılabilir.

Farklı yaş grubundaki katılımcıların fen deneylerine yönelik özyeterlik puanları incelendiğinde, 16 ve üzeri yaşa sahip öğrencilerin ölçeğin geneli ile planlama boyutundaki puan ortalaması diğer yaş grubundaki öğrencilerin puan ortalamalarından daha yüksek bulunmuştur (Tablo 10). Bu durum, yaş ilerledikçe özel yetenekli öğrencilerin fen deneylerine yönelik özyeterliklerinin yükseldiğini göstermektedir. Ayrıca bir üst yaş grubundaki katılımcıların puan ortalamalarının daha yüksek olması, bu sonucu desteklemektedir (Tablo 9). Bununla birlikte BİLSEM'de son program olan proje üretimi ve yönetimindeki katılımcıların planlama alt boyutundan elde ettikleri puan ortalamasının diğer programlardaki katılımcların puan ortalamalarından daha yüksek olduğu sonucuna ulaşılmıştır (Tablo 12). Bu programdaki katılımcıların 16 ve üzeri yaş aralığında olması, elde edilen bu iki sonucun paralellik gösterdiğini ortaya koymaktadır. Bir bilim insanı gibi karşılaştıkları problemleri çözme ve bu süreçte proje üretme ihtiyacı hisseden özel yetenekli öğrenciler (Özarslan, 2018), proje üretimi ve yönetimi programında kendi ilgi ve yetenekleri doğrultusunda özellikle fen bilimlerine yönelik proje çalışmaları yürütür, sorgulayarak ve davranışlarını düzenleyerek deneysel çalışmalar yapar ve proje çalışmalarında aktif görev alarak çalışma süresince yüksek performans gösterme eğiliminde olurlar (Curby, Rudasill, Rimm-Kaufman ve Konold, 2008). Dolayısıyla yürütülen bu öğretim faliyetlerinin özel yetenekli öğrencilerin fen deneylerine yönelik özyeterliklerinin yüksek olmasını sağladığ yorumu yapılabilir. Aynı zamanda özel yetenekli öğrenciler BİLSEM'de yürütülen bir üst öğretim basamağına geçtikçe fen deneylerine yönelik özyeterlik puan ortalamalarının da yükseldiği elde edilen bulgular arasındadır (Tablo 11). BİLSEM'lerde yürütülen her bir programın belli amaçları vardır. Özel yetenekli öğrencilere; Destek eğitimi programında temel becerileri kazandırmak, BYF programında bireysel yeteneklerinin farkına varmalarını sağlamak ve bu yeteneklerini geliştirmek, ÖYG programında ise özel yetenekleri doğrultusunda bilimsel ve sanatsal çalışmalar yürütmesini sağlamak amaçlanmaktadır. BİLSEM'de özel yetenekli öğrenciler son olarak Proje Üretimi ve Yönetimi programına alınırlar. Bu programda öğrencilerden güncel ve olası problemlere bilimsel çözüm üretmelerini sağlayacak proje çalışmaları yapmaları ve bu süreci yönetmeleri beklenmektedir (Barış, 2019).

Özellikle proje üretimi ve yönetimi programındaki öğrencilerin proje çalışmalarını devam ettirebilmeleri için proje çalışmalarında deneysel çalışmalar yapmaları önem arz etmektedir. Dolayısıyla özel yetenekli öğrencilerin bir üst programa geçtikçe deneysel çalışmalara yönelik özyeterliklerinin yükselmesinin sebebi, programların giderek öğrenci katılımını ön plana alan deneysel ve laboratuvar çalışmalarına yönelmesi gösterilebilir. Proje üretimi ve yönetimi programındaki katılımcıların özyeterlik puanlarının daha yüksek olması, bu sonucu destekler niteliktedir. Araştırmanın bulguları ve sınırlılıkları kapsamında aşağıdaki önerilerde bulunulmuştur:

Özel yetenekli öğrencilerin fen deneylerine yönelik özyeterliklerini yükseltmek için hem öğrenim gördükleri okullarında hem de BİLSEM'lerde deneysel çalışma yapabilecekleri ortamların oluşturulması önerilmektedir.

Özel yetenekli öğrencilerin eğitiminde bu öğrencilerin aktif rol aldığı fen bilimleri proje çalışmalarına ağırlık verilmesi önerilmektedir. 
Araştırmanın verileri gönüllü 197 özel yetenekli öğrenciden toplanmıştır. Araştırmanın kapsamı farklı bölge ve öğrencileri içerecek şekilde genişletimesi, elde edilen bulguların daha ayrıntılı yorumlanması ve karşılaştırılması açısından önemli görülmektedir.

Araştırmada nicel araştırma yönteminden tarama deseni tercih edilmiştir. Öğrencilerin fen deneylerine yönelik özyeterliklerinin nasıl olduğunu derinlemesine araştırmak için nitel araştırma desenleri kullanılabilir.

\section{Kaynakça}

Ahmad, C.N.C., Osman, K., Halim, L., \& Noh, N.M. (2014). Predictive relationship between physical and psychosocial aspects of science laboratory learning environment among secondary school students in Malaysia. Procedia - Social and Behavioral Sciences 116, 158-162.

Akbaş, M., \& Çetin, P.S. (2018). Üstün yetenekli öğrencilerin çeşitli sosyobilimsel konulara ilişkin argümantasyon kalitesinin ve informal düşünme becerisinin incelenmesi. Necatibey Eğitim Fakültesi Elektronik Fen ve Matematik Eğitimi Dergisi, 12(1) , 339-360.

Alpaut, O. (1993). Fen eğitiminin verimli ve işlevsel hale getirilmesi. Ortaöğretim Kurumlarında Fen Öğretimi ve Sorunları Sempozyumu. Ankara: TED.

Akar, Ö. (2011). İlköğretim okullarının başarı durumlarına göre yöneticilerin duygusal zekalarn ile öğretmenlerin özyeterlilikleri arasındaki ilişkinin belirlenmesi (Ankara ili örneği). Doktora Tezi. Gazi Üniversitesi, Eğitim Bilimleri Enstitüsü, Ankara.

Arık, S., \& Benli-Özdemir, E. (2016). Fen ve teknoloji öğretmen adaylarının fen laboratuvarına yönelik metaforik algıları. Kastamonu Ĕ̆itim Dergisi, 24(2) ,673-688.

Arzi, H. (2003). Enhancing science education laboratory environment: More than wall, benches and widgets, In B.J. Fraser, \& K. G. Tobin (Eds.). International Hanbook of Science Education, Vol (1), Netherlands: Kluwer Academic Publishers.

Aydıner, B. B. (2011). Üniversite öğrencilerinin yaşam amaçlarının alt boyutlarının genel öz-yeterlik yaşam doyumu ve çeşitli değişkenlere göre incelenmesi. Yüksek Lisans Tezi. Sakarya Üniversitesi, Eğitim Bilimleri Enstitüsü, Sakarya.

Backus, L. (2005). A year without procedures. The Science Teacher, 72(7), 54-58.

Ballen, C. J., Wieman, C., Salehi, S., Searle, J. B., \& Zamudio, K. R. (2017). Enhancing diversity in undergraduate science: Self-efficacy drives performance gains with active learning. CBE Life Sciences Education, 16(4), 1-6.

Barış, N. (2019). Bilsem'de görev yapan fen bilimleri ve matematik öğretmenlerinin stem eğitim uygulamalarının araştırılması. Yüksek Lisans Tezi. Hacettepe Üniversitesi, Eğitim Bilimleri Enstitüsü, Ankara.

Bandura, A. (1997). Self-efficacy: The exercise of control. New York, NY: Freeman.

Chen, S., Huang, C.C., \& Chou, T.L. (2016). The effect of metacognitive scaffolds on low achievers' laboratory learning. International Journal of Science and Mathematics Education, 14, 281-296.

Clotfelter, C.T., Ladd, H.F., \& Vigdor, J.L. (2007). How and why do teacher credentials matter for student achievement? CALDER Working Paper 2. Washington: The Urban Institute. 
Coleman, L.J., Micko, K.J., \& Cross, T.L. (2015). Twenty-five years of research on the lived experience of being gifted in school:Capturing the students' voices. Journal for the Education of the Gifted 38(4), 358-376.

Cullin, M., Hailu, G., Kupilik , M., \& Petersen, T. (2017). The effect of an open-ended design experience on student achievement in an engineering laboratory course. International Journal of Engineering Pedagogy. 7(4), 102-116.

Curby, T.W., Rudasill, K.M., Rimm-Kaufman, S.E., \& Konold, T.R. (2008). The role of social competence in predicting gifted enrollment. Psychology in the Schools, 45, 729-744.

Çepni S., \& Ayvac1, Ş.H. (2016). Laboratuvar destekli fen ve teknoloji öğretimi. Pegem Akademi, Ankara.

Çepni, S., Kaya, A., \& Küçük, M. (2005). Fizik öğretmenlerinin laboratuarlara yönelik hizmet içi eğitim ihtiyaçlarının belirlenmesi. Türk Ĕ̆itim Bilimleri Dergisi, 3(2), 181-194.

Chiang, C. Y., Huang, H. W., Chen, S. Y., Chen, Y. A., Chang, Y. M., \& Huang, H. J. (2020). An authentic inquiry-based laboratory module for introducing concepts about volatile-mediated communication resulted in stronger students' self-efficacy. Biochemistry and Molecular Biology Education, 1-11.

Damerau, K. (2012). Molekulare und Zell-Biologie im Schülerlabor - Fachliche Optimierung und Evaluation der Wirksamkeit im BeLL Bio (Bergisches Lehr-Lern-Labor Biologie). Dissertation. Bergische Universität Wuppertal

Damerau, K. (2013). Entwicklung eines Messinstruments zur Erfassung der Experimentbezogenen Selbstwirksamkeitserwartung, 15. Frühjahrschule der Fachsektion Didaktik der Biologie im VBIO, Universitaet Leipzig, Deutschland, 18-21.03.2013, Leipzig, Deutschland.

Ferrell, B., \& Barbera, J. (2015). Analysis of students' self-efficacy, interest, and effort beliefs in general chemistry. Chemistry Education Research and Practice, 16(2), 318-337.

Fraenkel, J. R., \& Wallen, N. E. (2006). How to design and evaluate research in education. (6 ${ }^{\text {th }}$ ed.) New York: McGraw-Hill.

Freeman, S., Eddy, S.L., McDonough, M., Smith, M.K., Okoroafor, N., Jordt, H., \& Wenderoth, M.P. (2014). Active learning increases student performance in science, engineering, and mathematics. Proceedings of the National Academy of Sciences, 111(23), 8410-8415.

Gutierez, S.B. (2015). Collaborative professional learning through lesson study: Identifying the challenges of inquiry-based teaching. Issues in Educational Research, 25(2), 118-134.

Hackling, M., Goodrum, D., \& Rennie, L. (2001). The state of science in Australian secondary schools. Australian Sciences Teachers' Journal, 47(4), 12-17.

Hassi, A. (2016). Effectiveness of early entrepreneurship education at the primary school level: Evidence from a field research in Morocco. Citizenship, Social and Economics Education, 15(2), 83- 103.

Hiller, S. E., \& Kitsantas, A. (2016). The validation of the citizen science self-efficacy scale (CSSES). International Journal of Environmental \& Science Education, 11(5), 543-558.

Hofstein, A., \& Lunetta, V.N. (2004). The laboratory in science education: Foundations for the twenty-first century. Science education, 88(1), 28-54. 
Karakolcu-Yazıcı, E., \& Özmen, H . (2015). Fen ve teknoloji öğretim programında yer alan deney ve etkinliklerin uygulanabilirliğine ilişkin öğretmen görüşleri. Amasya Üniversitesi Eğitim Fakültesi Dergisi, 4(1), 92-117.

Karasar, N.(2006). Bilimsel araştırma yöntemi. Ankara: Nobel Yayın Dağıtım.

Kılıç, D., Keleş, Ö., \& Uzun, N. (2015). Fen bilimleri öğretmenlerinin laboratuvar kullanımına yönelik özyeterlik inançları: Laboratuvar uygulamaları programının etkisi. Erzincan Üniversitesi Ĕ̆itim Fakültesi Dergisi, 17(1), 218-236.

King, W. R., \& He, J. (2005). Understanding the role and methods of meta-analysis in IS research. Communications of the Association for Information Systems, 16, 665-686.

Kramer, N. C., \& Winter, S. (2008). Impression management 2.0: The relationship of self-esteem, extraversion, self-efficacy, and self-presentation within social networking sites. Journal of Media Psychology, 20(3), 106-116.

Kwok, P.W. (2015). Science laboratory learning environments in junior secondary schools. AsiaPacific Forum on Science Learning and Teaching. 16(1), 1-28.

Lacey, M. M., Campbell, S. G., Shaw, H., \& Smith, D. (2020). Self-selecting peer groups formed within the laboratory environment have a lasting effect on individual student attainment and working practices. FEBS Open Bio, 10(2020), 1194-1209.

Lazarowitz, R., \& Tamir, P. (1994). In Handbook of research on science teaching and learning; Gabel, D. L., Ed.; Macmillan: New York, U. S. A.

Lopatto D. (2007). Undergraduate research experiences support science career decisions and active learning. CBE-Life Sciences Education, 6, 297-306.

MEB. (2017). Çocuk Gelişimi ve Eğitimi. Üstün zekahlar ve özel yetenekliler. Ankara: MEB Yayınevi.

MEB. (2018). İlköğretim Fen Bilimleri Dersi (3,4,5,6,7 ve 8. Sinıflar) Öğretim Programı. Ankara: MEB Yayınevi.

McBride, E., Oswald, W. W., Beck, L. A., \& Vashlishan Murray, A. (2020). I'm just not that great at science: Science self-efficacy in arts and communication students. Journal of Research in Science Teaching, 57(4), 597-622.

Meltzer, L. (Ed.). (2018). Executive function in education: From theory to practice. Guilford Publications.

Nabavi, R.T. (2012). Bandura's social learning theory \& social cognitive learning theory. Theory of Developmental Psychology, 1-24.

Özarslan, M. (2018). The impact of biology project studies on the scientific attitudes of gifted and talented students. Erciyes Journal of Education 2(2), 75-93.

Özbay, Y. (2013). Üstün Yetenekli Çocuklar Ve Aileleri. Ankara, T.C. Aile ve Sosyal politikalar Bakanlığı.

Pareek, R.B. (2019). An assessment of availability and utilization of laboratory facilities for teaching science at secondary level. Science Education International, 30(1).

Prabha, S. (2016). Laboratory experiences for prospective science teachers: A meta-analytic review of 1ssues and concerns. European Scientific Journal 12(34), 235-250. 
Randal, D. M. (2010). Science in the Liberal arts curriculum. In J. Meinwald \& G. Hildebrand (Eds.), Science and the educated American (pp. 9-22). Cambridge, MA: Academy of Arts \& Sciences.

Rockstroh, A. H. (2013). Teacher characteristics on student achievement: an examination of high schools in Ohio. Unpublished Master Thesis, Kansas City, Martin School of Public Policy and Administration.

Sarıoğlan, A.B. (2015). Ortaokul öğrencilerinin fen bilimleri dersinde laboratuar kullanımına ilişkin görüşleri. Eğitim ve Öğretim Araştırmaları Dergisi, 4(4), 333-340.

Schreglmann, S. (2016). Türkiye'de üstün yetenekli öğrenciler ile ilgili yapılan yükseköğretim tezlerinin içerik analizi (2010-2015). Üstün Yetenekliler Eğitimi Araştırmaları Dergisi, 4(1), 14-26.

Shapiro, C., Moberg-Parker, J., Toma, S., Ayon, C., Zimmerman, H., Roth-Johnson, E. A., Hancock, S.P., Levis-Fitzgerald, M., \& Sanders, E. R. (2015). Comparing the impact of coursebased and apprentice-based research experiences in a life science laboratory curriculum. Journal of microbiology E biology education, 16(2), 186.

Shen, K.M., Lee, M.H., Tsai, C.C., \& Chang, C.Y. (2016). Undergraduate students' earth science learning: relationships among conceptions, approaches, and learning self-efficacy in Taiwan. International Journal of Science Education, 38, 1527-1547.

Stuckey, M., Hofstein, A., Mamlok-Naaman, R., \& Eilks, I. (2013). The meaning of 'relevance' in science education and its implications for the science curriculum. Studies in Science Education, 49, 1-3.

Tarkın, A., \& Uzuntiryaki, E. (2012). Öğretmen adaylarının özyeterlik inançları ve mesleğe yönelik tutumlarının kanonik korelasyon analizi ile incelenmesi. Illköğretim Online, 11(2), 332341.

Tokuhama-Espinosa, T. (2015). The new science of teaching and learning: Using the best of mind, brain, and education science in the classroom. Teachers College Press.

Turner, R.C., \& Lindsay, H.A. (2003). Gender differences in cognitive and non-cognitive factors related to achievement in organic chemistry. Journal of Chemical Education, 80(5), 563-568.

Usher, E. L., \& Pajares, F. (2009). Sources of self-efficacy in mathematics: A validation study. Contemporary Educational Psychology, 34, 89-101.

Wardani, T. B., \& Winarno, N. (2017). Using inquiry-based laboratory activities in lights and optics topic to improve students' understanding about nature of science (NOS). Journal of Science Learning, 1(1), 28-35.

Yavuz, S., \& Akçay, M. (2017). Bilgisayar destekli öğretim ile laboratuar destekli öğretimin öğrencilerin ders başarılarına ve derse karşı tutumlarına etkisinin incelenmesi. Karaelmas Eğitim Bilimleri Dergisi, 5(1), 39-48.

Yazıcı, M., \& Kurt, A. (2018). Ortaokul fen bilimleri dersinde laboratuvar kullanımının öğretmen ve öğrenci görüşleri doğrultusunda incelenmesi. Bayburt Eğitim Fakültesi Dergisi, 13(25), 295320.

Yılmaz, M. (2018). Deneye ilişkin özyeterlik ölçeği: Türkçe'ye uyarlama, geçerlik ve güvenirlik çalışması. Kastamonu Education Journal, 26(2), 475-486. 